\title{
PERSPEKTIF AL-QUR'AN DAN UNDANG-UNDANG TENTANG GURU PROFESIONAL
}

\author{
Wasehudin* \\ Universitas Islam Negeri SMH Banten \\ *E-mail: wasehudin@uinbanten.ac.id
}

\begin{abstract}
This research is motivated by a high demand in the world of education, especially the professional educator. Anxiety of students when they are in class or classroom is considered a prison for the students is evidence of a failure in education. For that reason the idea in searching professional educator model from The Qur'an perspective should always be sought; how the pattern and model of professional ideal educator in the Islamic view. The approach used in this research is qualitative; the data used is documentary data both secondary and primary date which then dissected by using descriptive analysis approach. In the Qur'an perspective, especially in Sura Ali Imran: 159, it is stated that the professional teacher is able to master the material and methodology simultaneously. They can not be separated from one another. In addition, the teacher is said to be a professional when he or she becomes a role model which must be obeyed (digugu) and imitated (ditiru) when he is both in the environment of the educational institution and in the society where he lives and interacts.
\end{abstract}

Key word: Al-Qur'an, Master, and Professionalism

\begin{abstract}
ABSTRAK
Penelitian ini dilatarbelakangi oleh tuntutan yang begitu besar dalam dunia pendidikan terutama sekali guru profesinal. Kegundahan para peserta didik ketika berada dalam ruang kelas atau kelas dianggap sebagai penjara bagi para siswanya merupakan bukti adanya kegagalan dalam sebuah pendidikan. Untuk itu gagasan dalam pencarian model pendidik profesional perspektif Al-Qur'an harus senantiasa dicari; bagaimana pola maupun model guru profesional yang ideal dalam pandangan Islam. Pendekatan yang digunakan dalam penelitian ini bersifat kualitatif; data yang digunakan adalah data yang bersifat dokumenter baik data yang bersifat sekunder maupun primer yang kemudian dibedah dengan menggunakan pendekatan deskriptif analisis. Perspektif Al-Qur'an, khususnya dalam Surat Ali Imran: 159, menyatakan bahwa guru dikatakan profesional apabila ia mampu menguasai materi dan metodologi secara bersamaan. Keduanya tidak bisa dipisabkan antara satu dengan yang lainnya. Selain daripada itu guru dikatakan professional manakala ia menjadikan role model (uswah hasanah) yang harus digugu dan ditiru baik ketika ia berada dalam lingkungan institusi pendidikan maupun dalam lingkungan masyarakat dimana ia tinggal dan berinteraksi.
\end{abstract}

Kata Kunci: Al-Qur'an, Guru, dan Profesionalitas 


\section{PENDAHULUAN}

Al-Qur'an merupakan Sabda Tuhan untuk segala makhluk-Nya. Oleh karenanya Al-Qur'an sebagai sebuah sumber sejatinya harus dijadikan sebagai petunjuk bagi setiap manusia sehingganya Kitab ini akan menjadi rujukan sentral dalam segala bentuk kajian keislaman dan kemanusiaan. AlQur'an bukan saja akan memberikan petunjuk bagi setiap manusia melainkan akan menghantarkan manusia pada ruang kebahagiaan jika Kitab Suci ini dipelajari dengan Penuh kesungguhan dan keseriusan. Dengan demikian terobosan untuk mencarikan sebuah metode dalam mempelajari Al-Qur'an harus senantiasa ter-afgread sehingga Kitab Suci ini bukan hanya mampu menjadi inspirasi moral akan tetapi seklaigus dapat dijadikan sebagai ruujukan sentral bagi pemecahan persoalan yang timbul kemudian (Ahmad Syafii Maárif, 1993: 146). Melakukan analisa yang mendalam dan berkesinambungan (kontinyuitas) terhadap kandungan ayat-ayat Al-Qur'an disepanjang kehidupan merupakan bagian yang tak terelakkan lagi sebab kandungan ayat-ayat dalam Kitab Suci ini harus senantiasa selaras dalam menjawab berbagai bentuk persoalan kekinian.

Isi kandungan Al-Qur'an memuat dua tema besar; pertama tema yang terkait dengan keimanan yang dalam terminologi agama disebut dengan aqidah; dan kedua tema yang terfokus dengan amaliah yang disebut dengan syariáh (Zakiah Daradjat, 2014: 19).Kontek Al-Qur'an sebagai sebuah petunjuk (budan) bagi umat manusia manakala isi maupun kandungan AlQur'an digali melalui pendapat para ahli yang disesuaikan dengan peruntukannya sebab tidak ada satu bentuk kegiatan pun yang di-alpakan oleh Al-Qur'an. Oleh karenanya mencarikan sebuah terobosan untuk menggali dan memahami AlQur'an merupakan sebuah keharusan jika umat islam tidak mau ketinggalan zaman.

Di antara persoalan hidup yang hendak dicarikan solusinya adalah tantangan masa depan bagi profesionalisme keguruan yang bertitik tolak pada Al-Qur'an Surat Ali Imran Ayat 159:

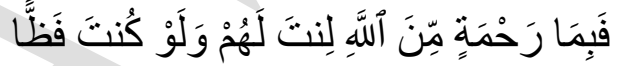

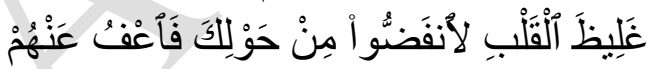

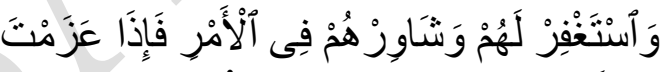

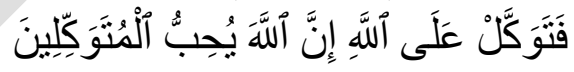
Artinya

Maka disebabkan rabmat dari Allab-lah kamu berlaku lemah lembut terbadap mereka. Sekiranya kamu bersikap keras lagi berbati kasar, tentulah mereka menjaubkan diri dari sekelilingmu. Karena itu maafkeanlah mereka, mohonkanlab ampun bagi mereka, dan bermusyawaratlah dengan mereka dalam urusan itu. Kemudian apabila kamu telah membulatkan tekad, maka bertawakkallab kepada Allah. Sesunggubnya Allah menyukai orang-orang yang bertawakeal kepada-Nya.

Di era millenial ini tantangan guru semakin kompleks dan pada saat yang bersamaan harus dicarikan solusinya oleh pihak terkait terutama oleh birokrasi maupun organisasi kependidikan seperti persatuan guru republik Indonesia (PGRI) terkait dengan metodologi 
pembelajaran yang tentunya sangat berbeda sebagaimana yang dilakukan oleh guru zaman dahulu dengan guru zaman sekarang. Guru zaman dahulu tidak dituntut untuk menguasai ilmu pengetahuan dan teknologi tapi guru zaman now penguasaan teknologi informasi merupakan sesuatu yang tidak bisa dipisahkan dalam kegiatan belajar mengajar di kelas (Dedi Supriadi, 1999: 73-74).

Profesionalisme kinerja bagi seorang pendidik akan terlaksana apabila seorang guru memiliki kepribadian yang efektif dimana guru mampu berinteraksi dimana ia berada terutama dalam lingkungan pendidikan (sekolah) dengan demikian diharapkan kebutuhan maupun tujuan pendidikan dapat tercapat dengan sendirinya (Surya, 2003: 290-292). Guru dikatakan professional apabila ia memiliki sejumlah kompetensi atau dengan kata lain memiliki sejumlah karakteristik profesionalisme. Guru profesional adalah guru yang memiliki sejumlah keahlian, diantaranya adalah kompetensi intelektual, sosial, spiritual, kepribadian, dan moral (Surya, 2003: 28).

Begitu juga dengan Undang-undang Sistem Pendidikan Nasional (SISDIKNAS) Nomor 20 Tahun 2003 BAB XI Pasal 40 Atay (2) dikatakan bahwasannya guru (tenaga pendidik) berkewajiban untuk menciptakan suasana pendidikan yang bermakna, menyenangkan, kreatif, dinamis, dan dialogis; mempunyai komitmen secara professional untuk meningkatkan mutu pendidikan; dan memberi teladan serta menjaga nama baik lembaga, profesi, dan kedudukan sesuai dengan kepercayaan yang diberikan kepadanya.

\section{METODE PENELITIAN}

Dalam mengembangkan ilmu-ilmu keagamaan harus dimulai dari kerangka berfikir antisipatif bukan reaktif. Menyalahkan sarjana muslim yang menggunakan kebenaran wahyu sebagai postulat merupakan pemikiran reaktif padahal dalam agama manapun yang disebut dengan Kitab Suci pasti memiliki kebenaran mutlak. Begitu juga dengan Al-Qur'an dalam islam yang dijadikan sebagai pelita dan penjernih pada saat kita bingung baik yang disebabkan dengan banyaknya teori maupun brbeda pandangan dalam pemaknaan (Taufik Abdullah Ed., 2004: 72-75). Begitu juga dalam kajian perspektif Al-Qur'an tentang guru professional merupakan bagian dari studi terhadap ayat-ayat AlQur'an yang terkait dengan profesionalisme kegruan melalui pendapat para mufassir maupun menelaah terhadap buku-buku yang terkait dengan profesionalitas guru.

Jenis penelitian ini termasuk dalam kategori penelitian kewahyuan sehingga pendekatan yang digunakan dalam kajiannya adalah pendekatan Sabda Tuhan yang dikorelasikan dengan Undang-undang maupun Peraturan Pemerintah (PP)terkait dengan profesionalismeguru sebagaimana yang terdapat dalam Undang-undang Guru dan Dosen Nomor 14 Tahun 2005 dan Peraturan Pemerintah Nomor 74 Tahun 2008. Jenis data yang digunakan dalam penelitian ini adalah jenis data kewahyuan dan perundang-undangan, 
kedua jenis data tersebut termasuk dalam kategori data literer kepustakaan yang dijadikan sebagai sumber primer. Sumber data primer dalam kajian ini akan mengacu pada Al-Qur'an dan Tafsirnya, Hadits dan syarahnya, serta Undang-undang maupun Peraturan Pemerintah (PP) terkait dengan guru dan profesionalitasnya. Selain data primer sebagai data pokok, penulis juga akan menggunakan data yang bersifat sekunder baik yang berupa tulisan, wawan cara dengan para ahli maupun karya-karya lain yang terkait dengan kajian penelitian ini. Setelah keduanya terkumpul; dataprimer maupun data sekunderkemudian penulis telaah sesuai dengan peruntukkannyadimana data yang sudah terkumpul disusun menjadi sebuah teks yang bersifat naratif yang kemudiandikorelasikan dengan bangunan kerangka teoretis yang sudah ada sebelumnya untuk diuji dengan tetap berpegang pada pendekatan filosifis hingga sampai pada proses penyimpulan (Muhyar Fanani, 2010: 11-12).

\section{HASIL DAN PEMBAHASAN}

Al-Qur'an sebagai Mr google-nya segala persoalan sudah barang tentu berbagai jenis jawaban dengan penuh kepastian ada di dalamnya karena ia bukan Kitab yang diperuntukkan masa kenabian Muhammad hingga para sahabatnya melainkan juga Kitab Undang-undang kemanusiaan maupun kealaman yang dibuat oleh Allah SWT. sebagai Tuhan hingga berakhirnya zaman kehidupan. Jika kita hendak mencarikan jawaban atas suatu persoalan misalnya yang terkait dengan pola, model, maupun karakter guru profesional sebagai ujung tombak dalam dunia pendidikan maka Al-Qur'an sudah mempersiapkan jawabannya.

\section{Profesionalitas Guru dalam Undang- undang}

Dalam Undang-undang guru dan Dosen Nomor 14 Tahun 2005 Bab I Pasal 1 dinyatakan: "Guru adalah pendidike profesional dengan tugas utama mendidik, mengajar, membimbing, mengarabkan, melatih, menilai, dan mengevaluasi peserta didik pada pendidikan anak usia dini jalur pendidikan formal, pendidikan dasar, dan pendidikan menengah".

Begitu juga dalam Undang-undang SISDIKNAS Nomor 20 Tahun 2003; guru profesional merupakan pendidik yang bertugas untuk merencanakan, mendesain, serta mengimplementasikan segala bentuk kegiatan baik yang terkait dengan mata pelajaran maupun diluar mata pelajaran seperi shoft skill dalam bentuk bimbingan dan pelatihan yang dilakukan secara kontinyu dan berkesinambungan agar terjadinya sebuah perubahan. Guru dikatakan profesionalan apabila ia memiliki segudang cara yang dapat dilakukan agar terjadinya sebuah perubahan ke arah yang lebih baik.

Istilah lain dari guru profesional adalah guru inspiratif sebagaimana yang digagas oleh Ngaiun Naím. Guru dikatakan inspiratis apabila guru mampu melihat tantangan dijadikan sebagai sebagai peluang yang menarik untuk dikembangkan dan dari proses pengembangan tersebut akan membuahkan hasil yang gemilang. Atau dengan kata lain guru dikatakan inspiratif dan professional apabila ia bukan sekedar penyampai pesan (pos man) dan 
meninggalkan "kesan" melainkan juga mampu untuk mempengaruhi, mengendalikan, serta mengubah baik pola maupun gaya dari kehidupan peserta didik yang tidak sejalan dengan nilai-nilai luhur agama, budaya dan karakter bangsa. Dengan demikian guru inspiratif adalah guru yang mampu mengubah jalan hidup peserta didiknya untuk menjadi lebih baik (Ngainun Naím, 2009: 70)

Istilah guru inspiratif bukan merupakan gagasan awal dari Ngainun Naím karena pada mulanya istilah digagas dan dibidani oleh Seorang Inspirator ulung Renald Khasali. Bagi Khasali guru itu ada dua type: guru kurikulum dan guru inspiratif. Guru kurikulum merupakan guru pola tekstual yang tidak ubahnya bagaikan tukang bata yang hanya mampu mencetak bata tidak yang lainnya kendatipun dalam jumlah ribuan bahkan juta bata. Sedangkan guru inspiratif adalah guru kontekstual yang tidak hanya mampu menciptakan batu bata tapi juga ia mampu mendesain gerabah (tempat yang terbuat dari tanah liat) yang beraneka ragam seperti gentong, coet sambal, kendi minum, maupun celengan yang digunakan untuk mengumpulkan uang recehan. Dengan demikian guru kurikulum adalah guru silabus dan RPP, ia merasa bangga dan gembira apabila ia telah menyelesaikan pembelajaran sesuai dengan acuan tersebut (Silabus dan RPP) dan jumlah guru yang memiliki type semacam ini berjumlah $99 \%$ dari sejumlah sampel yang ia temukan. Jika kita renungkan, maka bisa dijawab dengan jujur dari hati kita masing-masing jumlah guru kurikulum lebih mendominasi daripada jumlah guru inspiratif, belum lagi ketika terjadi penggabungan dari pola gaya mengajarnya bisa jadi akan banyak sebutan lain selain guru kurikulum melainkan guru kurikulum plus diktatoris. Indikator yang digunakan oleh type guru kurikulum ini lebih bersifat angkais (kuantitatif) yang lebih menitik beratkan pada pola satu kecerdasan yang bernama kecerdsan intelektual quesen (IQ) semata. Berbeda dengan guru inspiratif; bagi Khasali gusu inspiratif adalah sosok modifikator ulung dan ia akan selalu mengadakan perubahanperubahan baik dalam bentuk pola maupun tindakannya dalam mendidik (Harian Kompas, 2007: 29 Agustus). Guru yang semacam ini biasanya lebih banyak mendidik dan sedikit mengajar sehingganya yang ia bawa bagaimana memotivasi peserta didiknya untuk berfikir kreatif (maximum thinking) dalam melihat alam sekitarnya; apa (ontology), bagaimana (episthimology), dan untuk apa (axiology) dalam segala bentuk persoalan. Dengan demikian guru inspiratif adalah guru yang mampu menanamkan nilai dalam segala berbagai persoalan kehidupan (living velue education), namun sayangnya guru semacam ini masih terlalu sedikit bahkan bisa jadi jumlah jari-jemari manusia masih cukup untuk menghitungnya. Fenomena ini merupakan suatu bentuk tantangan yang sagat menarik sehingga kita tergugah untuk segera mengadakan perubahan dari guru kelas menjadi guru alam.

Bagi E. Mulyasa istilah lain dari guru profesional adalah seorang aktor emancipator yang tangguh baik di dalam 
kelas maupun diluar kelas (E. Mulyasa, 2008: 58-61).Sebagai aktor maka ia dituntut untuk dapat mengarahkan para peserta didik atas dasar panggilan jiwa yang sangat mendalam bukan atas dasar kewajiban selaku guru melainkan sebagai pendidik yang tulus dan ikhlas baik dalam menyampaikan mata pelajaran maupun gagasan untuk terjadinya sebuah perubahan bagi para peserta didiknya. Oleh karena tugas guru sebagai seorang aktor bukan hanya mentransferkan sejumlah materi yang harus diselesaikan dengan jumlah dan waktu yang sama (sesuai silabus \& RPP) melainkan lebih jauh daripada itu; misalnya bagaimana guru memahami seluk beluk kepribadian peserta didiknya mulai dari latarbelakang orang tua peserta didik; tingkat perekonomiannya; kehidupan dilingkungan keluarganya; tempat tinggalnya; hingga kepada teman bergaulnya baik di sekolah, masyarakat maupun dilingkungan keluarganya. Hal ini diharapkan guru sebagai aktor dapat memahami serta menyelami dari kondisi maupun emosional para peserta didiknya. Dengan cara inilah sang aktor dapat mengontrol secara efektif untuk kemudian diadakan tindakan seperlunya.Selain sebagai aktor, guru profesional juga bisa dikatakan sebagai emansipator. Tipe guru semacam ini ia akan melihat sesuatu diluar yang Nampak (makna tersisirat) selain dari yang tampil kepermukaan (makna dhohir/tersurat) yang tidak selesai sampai disitu melainkan ia senantiasa mencari peluang agar yang tersirat maupun tersurat menjadi potensi besar yang harus dimaksimalkan pengembangan untuk modal dimasa-masa mendatang karena ia mengakui seringkali pengalaman, pengakuan serta dorongan seringkali dapat membebaskan problematika peserta didik dari self image yang kurang menyenangkan seperti adanya perasaan minder, malu, sifat murung, tidak percaya diri hingga sifat egois yang menagnggap lainnya tidak sepadan dengan dirinya sendiri. Terjadinya proses penilaian yang berlebihan baik sifat minder maupun angkuh-diri (sombong) tentunya sebagai emansipator akan bisa menyelesaikan kedua sifat tersebut; perasaan minder dan sombong akan berubah menjadi peserta didik yang percaya diri dan peserta yang tawadhu bisa memahami nilai-nilai kekurangan orang lain sebagaimana sifat ke-egoisan maupun keserakahan adalah bagian dari sifat negatif yang harus segera dihilangkan. Dengan kata lain guru emansipator adalah guru yang dapat mengembangkan serta mengembalikan potensi positif bagi para peserta didik. Emansipator bagian lain dari guru sebagai motivator yang selalu memberikan semangat dalam berbagai kesempatan; guru motivator adalah mereka yang memiliki kepekaan sosial yang tinggi karena ia menyadari bahwasannya yang ia hadapi bukan benda mati sebagaimana yang dilakukan oleh tukang bata dengan tanah liatnya, disinilah letak kepiawian guru motivator yang senantiasa melihat peserta didik dengan keunikannya sendiribaik ketika di dalam kelas maupu di luar kelas. Pola yang dikembangkan bagi tipikal guru sang motivator lebih pada aspek pasikologis maupun sentuhan jiwa 
sehinganya bentuk dorongan yang datang dari dalam diri siswa (faktor internal) dipandang sebagai modal besar untuk mengkreatifkan peserta didik.

Apapun bentuk dan namanya: baik guru profesional; guru inspiratif; guru sebagai aktor; guru inspiratory maupun guru motivator, guru tetaplah seorang pengendali dari penumpang yang bernama peserta didik yang memiliki sejuta keanekaragaman serta keunikannya masing-masing, ditangan gurulah masa depan bangsa hendak dibawa kemana disinilah bagian dari pemaknaan bahwa guru merupakan kata kunci utama dalam perubahan sebuah bangsa. Rendahnya gaji guru yang disebabkan oleh kebijakan yang tidak berpihak akan berdampak pada pembangunan masa depan bangsa. Ketidakjelasan alokasi anggaran 20\% sebagaimana yang telah menjadi amanat Undang-undang 1945 Pasal 31 Ayat 4 dari alokasi Anggaran Pembiayaan Belanja Negara (APBN) masih tidak sebanding jika ukur dengan besarnya alokasi pembangunan fsik; maka tidaklah diherankan jika uang triluan rupiah yang diperuntukan untuk merubah wajah negeri ini selalu mengalir pada pundipundi oknum pejabat negara mulai dari kasus hambalang, BLBI yang tidak kunjung selesai hinga kasus E-KTP yang dapat menyeret ketua anggota dewan yang terhormat Setya Novanto beserta kroni-kroninya. Pembangunan fisik memang diperlukan agar terjadi dan meningkatnya percepatan ekonomi akan tetapi pembangunan mental lebih penting dari sekedar bangunan materi, sebab jika manusia indonesia jika mentalitasnya sudah terbangun, maka dengan sendirinya bangunan fisikal akan lebih berkualitas. Pencanangan seperti ini sudah dimulai sejak pemerintah Susilo Bambang Yodoyono tanggal 2 Desember Tahun 2004. Kebijakan yang dikeluarkan oleh pemerintahan SBY merupakan bentuk terobosan dua langkah lebih maju ketimbangan pemerintahan sebelumnya dimana guru semaian kesejahteraan yang canangkan bagi para pahlawan tanpa jasa maupun Umar Bakri dengan meminjam istilah Iwan Fals sudah dengan sendirinya akan dapat mengubah suasana yang dapat memberikan semangat kepada sejumlah guru agar menyadari eksistensi dirinya sebagai manusia yang senantiasa digugu dan ditiru. Di sisi lain gagasan maupun terobosan kebijakan dari seorang SBY sering mendapatkan keritikan dari para guru honorer yang dipandang tidak adil dan masih memihak namun setidaknya terobosan tersebut harus dijadikan sebagai pola awal yang harus diikuti oleh pemerintahan selanjutnya terutama dalam menguraikusut nasib para guru honorer yang berujung pada ketidakpastian masa depan mereka.

Adanya kebijakan afirmasi dari pemerintahan SBY mestinya disambut baik oleh para Gubernur, Bupati maupun Walikota untuk tetap menganggarkan tunjangan kepada seluruh guru diwilayahnya masingmasing tanpa membedakan guru PNS dan swasta, namun sayangnya kebijakan keberpihakan terutama bagi para guru swasta masih dalam sebatas wacana atau kalaupun sudah dibuat peraturan daerahnya belum sebanding dengan 
penghasilan yang diperoleh oleh guru PNS sebagaimana diatur baik dalam Undang Guru dan Dosen Nomor 14 Tahun 2005, Undang-undang SISDIKNAS Nomor 20 Tahun 2003 maupun Undang-undang Otonomi Daerah (OTDA) Nomor 32 Tahun 2004.

Undang-undang Otonomi Daerah (OTDA) sebagaimana tertuang dalam Bab I Pasal 1. Disinyalir bahwasannya daerah diberikan hak, wewenang, dan kewajiban daerah otonom untuk mengatur dan mengurus sendiri urusan pemerintahan dan kepentingan masyarakat setempat sesuai dengan peraturan perundang-undangan. Lebih lanjut dalam Pasal 7 dinyatakan bahwasannya: "kewenangan daerah atau yang disebut dengan desentralisasi merupakan penyerahan wewenang pemerintaban oleh pemerintah pusat kepada daerah baik Gubernur, Bupati maupun Walikota untuke mengatur dan mengurus urusan pemerintaban dalam Sistem Negara Kesatuan Republike Indoensia (NKRI)".

Penguatan sebagai salah satu bentuk kebijakan afirmasi bagi para guru yang dilakukan oleh Pemerintah Daerah Tingkat I yang dipimpin oleh para Gubernur maupun Daerah Tingkat II yang dikepali oleh Bupati maupun Walikota dalam rangka memberikan tunjangan kepada guru PNS dan swasta tidaklah menyalahi Undang-undang apalagi setelah diterbaitkannya Undangundang Otonomi Daerah (OTDA) sebagai salah satu bentuk kewenangan yang menjadi dasar hukum yang diberikan pemerintah pusat kepada daerah untuk mengelola, memelihara yang didasarkan serta disesuaikan dengan daerahnya semata-mata untuk memenuhi kemakmuran rakyatnya baik yang terkait dengan pengaturan budget keuangan, hukum, dan pemerintahan itu sendiri (Wayong J:1979: 16).

Dibentuknya Undang-undang Otonomi Daerah (OTDA) merupakan bukti keseriusan pemerintah pusat untuk lebih meningkatkan serta mengoptimalkan pelayanan dan kesejahteraan kepada masyarakat hingga terciptanya pemberdayaan masyarakat secara mendiri serta diharapkan dapat berpartisipasi dalam proses perencanaan, pelaksanaan, dan pengawasan serta pelayanan kepada public (HAW. Widjaja, 2013: 58).Hal ini menuntut kepada Pemerintah Daerah baik tingkat I (gubernur) dan II (Bupati/Walikota) agar senantiasa berkreasi, berinovasi, serta berimprovisasi demi kemajuan daerahnya masing-masing (Hasbullah, 2006: 2).

Tuntutan kesejahteraan bagi para guru merupakan amanat Undang-undang yang didalamnya tidak mengenal dikotomi antara guru PNS dan swasta namun sayangnya realitas dilapangan Undang-undang SISDIKNAS Nomor 20 Tahun 2003 hanya sebatas guru PNS. Undang-undang SISDIKNAS tersebut khususnya Bab XI Pasal 40 disebutkan bahwasannya "pendidik dan tenaga kependidikan berhak memperoleh penghasilan dan jaminan kesejabteraan social yang pantas dan memadai; berbak mendapatkan penghargaan sesuai dengan tugas dan prestasi kerjanya; berbak mendapatkan pembinaan karier sesuai dengan tuntutan pengembangan kualitas; berbak mendapatkan perlindungan bukum dalam melaksanakan tugas dan 
hakatas hasil kekayaan intelektual; dan berbak mendapatkan kesempatan untuk menggunakan sarana dan fasilitas pendidikan untuk menunjang kelancaran pelaksanaan tugas". Paparan di atas jelas dan gambelang tidak terlihat adanya perbedaan labelis antara guru negeri dan swasta untuk sama mendapatkan hak dan kewajiban dari negara.

\section{AL-QUR'AN DAN GURU PROFESIONAL}

Al-Qur'an baik sebagai Sabda Tuhan maupun Kitab agama bagi seluruh umat islam sudah barang tentu akan menjadi rujukan sentral sebagaimana yang ia deklarasikannya sendiri bahwasannya di dalamnya terdapat petunjuk bagi orang-orang yang bertaqwa. Selain dari itu berpegang teguh terhadap Al-Qur'an merupakan bagian dari pencaharian hidayah (petunjuk) yang bertujuan untuk menyucikan dan mengajari manusia dengan perantaraan pena-Nya.

Sifat Rahman (Maha Pengasih) dan Rahim (Maha Penyayang)-Nya Tuhan sifat tersebut dituntut untuk diteladani oleh setiap muslim sehingga rahmat dan kasih sayang Tuhan dapat dirasakan oleh setiap makhluk Tuhan (Harun Nasution, 1986: 136).

Kontek sifat tersebut jika dihungkan dengan tugas guru sebagai pendidik, pengayom, pemberi inspirator maupun motivfator hendaknya didasarkan atas dasar keikhlasan dari lubuk hati yang sangat dalam. Keikhlasan bagi seorang pendidik merupakan modal terbesar dalam membina masa depan anak bangsa karena belajar sejatinya adalah mengembangkan prilaku peserta didik; oleh karenanya tugas utama guru sebagai pendidik, pengajar, pembimbing, pengarah, pelatih, dan penilai dalam setiap jenjang pendidikan merupakan tugas yang tidak dapat dipisahkan bagi guru professional (UU Sisdiknas No. 14 Bab I Pasal 1 Ayat 1).

Dalam Al-Qur'an Surat Ali Imran Ayat 159:

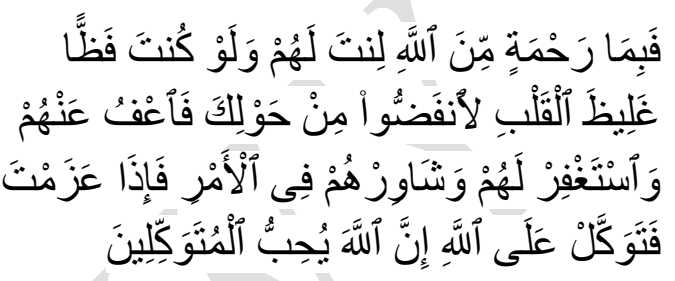

Artinya:

Maka disebabkan rabmat dari Allah-lah kamu berlaku lemah lembut terhadap mereka. Sekiranya kamu bersikap keras lagi berhati kasar, tentulah mereka menjaubkan diri dari sekelilingmu. Karena itu maafkeanlah mereka, mobonkanlah ampun bagi mereka, dan bermusyawaratlah dengan mereka dalam urusan itu. Kemudian apabila kamu telah membulatkan tekad, maka bertawakkallah kepada Allah. Sesunggubnya Allah menyukai orang-orang yang bertawakkal kepada-Nya.

merupakan modal dasar bagi Muhammad SAW. baik sebagai Nabi dan Rasul maupun sebagai manusia biasa yang hidup ditengah-tengah masyarakat Jahiliah dikala itu. Prilaku Muhammad sebagai salah satu bentuk manifestasi ayat tersebut bisa dijadikan sebagai bangunan pola bagi para pendidik dalam upaya memenuhi tingkat keprofesionalannya. Tindakan lemah lembut yang dilakukan oleh para guru merupakan sentuhan psikologis yang dapat membangkitkan kesemangatan peserta didik untuk mengenali serta 
mengoptimalkan potensi dirinya sendiri. Penebar kedamaiannَنْ merupakan bagian dari kompetensisosial yang harus dimiliki serta dijiwai oleh setiap pendidik. Kompetensi sosial yang harus dimiliki oleh setiap guru sebagaimana yang tercantum dalam Peraturan Pemerintah (PP) Nomor 74 Tahun 2008 disebutkan bahwasannya guru harus mampu berkomunikasi lisan, dan isyarat secara santun; menggunakan teknologi komunikasi dan informasi secara fungsional; bergaul secara efektif dengan peserta didik sesama pendidik, tenaga kependidikan, pemimpin satuan pendidikan, orang tua atau wali peserta didik; bergaul secara santun dengan masyarakat sekitar dengan mengindahkan norma serta sistem nilai yang berlaku; dan menerapkan prinsip persaudaraan sejati dan semangat kebersamaan.

Dalam kontek “" وَشَاوِزهُهْ فِى آلْأَمْرِ" maka segala bentuk urusan khususnya yang terkait dengan segala bentuk persoalan pendidikan hendaknya diselesaikan melalui pendekatan diskusi (bermusyawarah) karena inti dari kata wasyaawirhum menurut Quraish Shihab merupakan bentuk perintah (amr) yang harus membuahkan serta menghasilkan sesuatu yang terbaik sebagaimana yang terkandung dalam makna dasar dari kata tersebut yaitu mengeluarkan madu dari sarangnya (M. Quraish Shihab, 1996: 469).Sedangkan

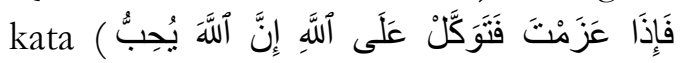
merupakan bagian dari tugas guru profesional tidaklah cukup hanya sebatas pemberian model bagi para peserta didiknya namun ada kekuatan lain yang dipandang bisa membantu agar terciptanya sebuah perubahan yang menjadi cita-cita bersama. Kekuatan dimaksud adalah untaian ketulusan doá dari sang guru kepada para peserta didiknya agar kelak ilmu yang diterimanya menjadi ilmu yang bermanfaat dan menjadikan anak didikan sebagai anak yang sholeh yang dapat berbakti kepada orang tua, agama, dan negaranya.

Doa yang tulus bagi seorang guru merupakan bagian dari kompetensi yang selama ini belum disikapi secara serius padahal bagi islam doa merupakan senjata yang ampuh bagi kaum muslimin untuk segera keluar dari segala bentuk persoalan yang ada. Kekuatan spiritual bagian dari profesionalitas guru sebagai pendidik sejati dalam pandangan pendidikan islam. Semakin kuat nila-nilai spiritual seorang guru maka semakin kuat nilai-nilai ke-Tauhidannya dan tauhidiah yang bisa menghantarkan kehidupan yang lebih baik untuk mencapai kebahagiaan yang hakiki baik di dunia maupun diakhirat nanti (Hilma Fauzia Ulfa dkk, 2017: 2).

Profesionalitas guru dalam pandangan ayat tersebut, doahendaknya dijadikan sebagai kekuatan supranatural yang harus menjadi dasar maupun core skill yang mampu menggerakan peserta didik dibalik kekuatan yang sesungguhnya. Selain daripada itu doa merupakan bentuk indikator dari keikhlasan guru dalam melaksanakan tugasnya serta bagian dari bentuk keteladanan yang sesungguhnya. Menjadi teladan (modelling/uswab hasanab) merupakan bagian yang tak terpisahkan 
(integral) dari seorang guru profesional. Menjadi guru profesional berarti harus siap menerima tanggung jawab sebagai teladan (modelling) (E. Mulyasa, 2008: 47). Dengan demikian profesionalitas guru dalam pandangan Al-Qur'an sejalan dengan kompetensi dasar yang menjadi prasyarat bagi guru profesional dimana guru tersebut harus memiliki empat kompetensi dasar sebagaimana yang diamanatkan dalam Undang-undang Nomor 14 Tahun 2005 tentang guru dan dosen (kompenetsi paedagogik, kepribadian, sosial, dan profesional).

Paradigma guru profesional perspektif penulis cukuplah berpegang kepada Surat Ali Imran Ayat 159 sebagai acuan menuju terciptanya guru profesional. Dalam kontek ayat dimaksud setidaknya guru professional

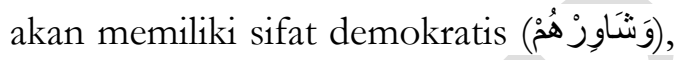
bersabar dan berlaku lemah lembut dalam menjalankan tugas mulianya (لِنَّ لَهُمْن), pemberi maaf serta konsisten terhadap tugas dan tanggung jawabnya, mampu bekerja sama (kooperatif) dan penyang baik dalam tindakan maupun

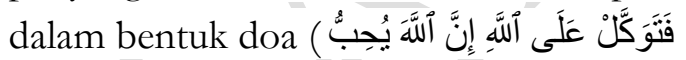
(ألْنَتَوَكِلِينَ).

\section{PENUTUP}

Bagi manusia yang beriman maka sudah pasti bahwasannya Al-Qur'an dan Al-Sunnah merupakan dasar sejati bagi kemanusiaan. Al-Qur'an merupakan jawaban dari segala bentuk maupun ragamnya persoalan yang pada umumnya melalui kisah maupun sejarah umat-umat terdahulu, tak terkecuali bangunan paradigma yang terkait dengan pola maupun model dari guru profesional.
Guru dikatakan professional manakala ia memiliki sifat shidik (benar), amanah (jujur), tanggung jawab, tabligh memiliki panggilan untuk menyerukan kebaikan, dan fatonah (cerdas) dalam berprilaku dan bertindak.

Guru dikatakan profesional apabila ia memiliki keimanan dan ketaqwaan (taubid) kepada Tuhan YME; memiliki akhlak mulia; arif dan bijaksana; demoratis; jujur; sportif; ikhlas dalam menjalankan tugasnya dengan indikator selalu mendoakan peserta didiknya agar menjadi anak yang berguna bagi nusa dan agamanya; serta menjadi teladan baik ketika berada dilingkungan sekolahnya maupun dalam lingkungan keluarga dan masyarakatnya. Itulah intisari makna dari

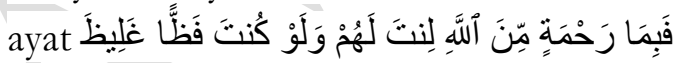

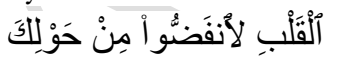

\section{REFERENSI}

Ahmad Syafií Maárif, (1993), Peta Bumi Intelektual Islam di Indonesia, Bandung: Mizan

Dedi Supriadi, (1999), Mengangkat

Citra dan Martabat Guru, Yogyakarta: Adicita Karya Nusa

E. Mulyasa, (2008), Menjadi Guru Profesional: Menciptakan

Pembelajaran Kreatif dan Menyenangkan, Bandung: Rosdakarya

Harian Umum Kompas (2007); Edisi 29 Agustus

Harun Nasution, (1986), Teologi Islam:

Aliran-aliran Sejarah Analisa 
Perbandingan, (Jakarta: Pustaka Nasional

Hasbullah, (2006), Otonomi Pendidikan:

Kajian Otonomi Daerah dan

Implikasinya terbadap

Penyelenggaraan Pendidikan,

Jakarta, Rajawali Press

HAW. Widjaja, (2013), Penyelenggaraan

Otonomi di Indonesia dalam

Rangka Sosialisasi UU No. 32

Tabun 2004, Jakarta: Rajawali

Press

Hilma Fauzia Ulfa dkk., (2017), Metode Pendidikan Taubid dalam

Kisah Ibrabim AS, (TARBAWI:

Indonesia Journal of Islamic

Education-Vol 3 No. 2 Tahun 2017)

Muhyar Fanani, (2010), Metode Studi

Islam; Aplikasi Sosiologi

Pengetahuan sebagai Cara Pandang,

Yogyakarta: Pustaka Pelajar

Ngainun Naím, (2009), Menjadi Guru

Inspiratif: Mempberdayakan dan

Mengubah Jalan Hidup Siswa,

Yogyakarta: Pustaka Pelajar

Surya, (2003), Percakap Perjuangan

Guru, Semarang: CV Aneka

Taufik Abdullah dan M. Rusli Karim

(Ed), (2004), Metodologi Penelitian

Agama; Suatu Pengantar,

Yogyakarta: Tiara Wacana

Undang-undang Guru dan Dosen

Nomor 14 Tahun 2005

Wayong J. (1979), Asas dan Tujuan

Pemerintahan Daerah. Jakarta:

Djambatan

Zakiah Daradjat, (2014), Ilmu Pendidikan

Islam, Jakarta: Bumi Aksara 